\title{
Distribution, ecology and status of an endemic shrew, Crocidura thomensis, from São Tomé
}

\author{
John Dutton and Jan Haft
}

\begin{abstract}
The São Tomé white-toothed shrew Crocidura thomensis is endemic to the island of São Tomé in the Gulf of Guinea. This species was discovered in 1886 and since then has been recorded from fewer than 10 locations. This paper summarizes all published and unpublished information on $\mathrm{C}$. thomensis. The species is currently listed by the IUCN as 'Insufficiently Known', but using the new IUCN Red List Categories is re-classified as 'Vulnerable B1 $+2 c^{\prime}$. Threats to the survival of C. thomensis include deforestation, plantation redevelopment and predation by introduced mammals.
\end{abstract}

\section{Introduction}

São Tomé, with an area of $857 \mathrm{sq} \mathrm{km}$, is the larger of the two islands that make up the Democratic Republic of São Tomé and Príncipe. It lies $255 \mathrm{~km}$ off the coast of Gabon in the Gulf of Guinea and the nearest land is Príncipe, $150 \mathrm{~km}$ to the N-NE (Figure 1). Geological evidence indicates that São Tomé has never been connected to Príncipe nor to mainland Africa (Exell, 1944; Heim de Balsac and Hutterer, 1982; Jones and Tye, 1988; Brühl, 1993; Jones, 1994), allowing the biota to evolve in isolation. This is shown by the large number of endemic taxa present, especially birds (Collar and Stuart, 1985; Günther and Feiler, 1985; Jones and Tye, 1988; Atkinson et al., 1991, 1994; Jones et al., 1991; Nadler, 1993; Peet and Atkinson, 1994) and plants (Exell, 1944, 1956; Brühl, 1993; Figueiredo, 1994).

When discovered in 1479, São Tomé was reported to be completely covered in rain forest (Exell, 1944; Hodges and Newitt, 1988). Much of this was cleared for plantation development, with the remaining primary forest restricted to higher altitudes and steep slopes (Exell, 1944). A survey in 1989 found that total forest cover was 91.1 per cent: 28.5 per cent primary, 30.2 per cent secondary and 32.4 per cent shade forest over cocoa plantations
(Interforest AB, 1990). Apart from nine bat species (Juste and Ibañez, 1994), the island was believed to be devoid of mammals when it was discovered (Exell, 1944), although subsequently 14 species were introduced (Dutton, 1994) and in 1886 a species of Soricidae was discovered (Bocage, 1887). Quite how this species became established on São Tomé remains a zoogeographical mystery (Heim de Balsac and Hutterer, 1982; Jones and Tye, 1988; Jones, 1994; Juste and $\mathrm{Fa}, 1994$ ).

\section{Discovery and classification}

The São Tomé white-toothed shrew Crocidura thomensis was first collected by Francisco Newton in 1886 (Bocage, 1887; Figure 2; Table 1). Newton had written 'that this species must be truly rare for it had escaped the researches of his [Newton's] predecessors and he was only able to obtain this single individual taken by chance' (Bocage, 1887). Newton collected his last specimen in 1896 (Bocage, 1904b; Figure 2; Table 1). Bocage (1887) described the species and wrongly recorded that it also occurred on Príncipe (Bocage, 1904a; Heim de Balsac and Hutterer, 1982; Jones and Tye, 1988). The specimens described by Bocage were preserved in the Bocage Museum, 


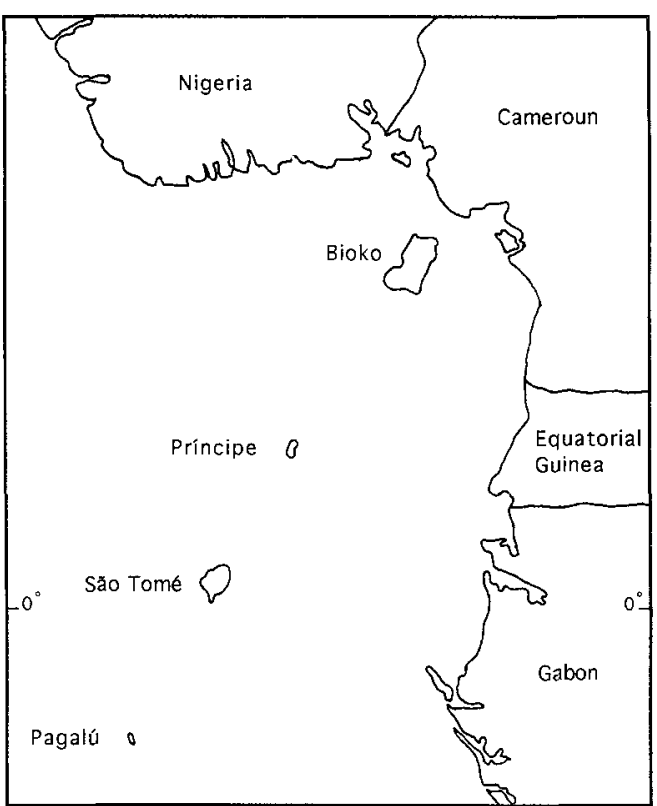

Figure 1. São Tomé in relation to the African mainland and the other Gulf of Guinea islands.

Lisbon, until 1910 when all but one specimen, attributed to Príncipe, were destroyed by fire (Heim de Balsac and Hutterer, 1982).

No other specimens of $C$. thomensis were collected until the early 1970s when R. de Naurois carried out a field search (Heim de Balsac and Hutterer, 1982). An initial examination of owl pellets revealed only bones of ship rats Rattus rattus, a bird and a mouse. Direct habitat searches were unsuccessful on the eastern coast between 200 and $300 \mathrm{~m}$ but searches between 700 and $800 \mathrm{~m}$ towards the centre of the island produced a series of specimens of $C$. thomensis (Figure 2; Table 1). Specimens of the shrew on Príncipe were also collected, allowing a re-examination of the Soricidae of the two islands. It was found that the species occurring on Príncipe was a subspecies of $C$. poensis, a widely distributed West African species, and that $C$. thomensis was endemic to São Tomé (Heim de Balsac and Hutterer, 1982). It should be noted that Nowak (1991) wrongly attributes C. thomensis to Príncipe and C. poensis to São Tomé.

$C$. thomensis is dark brown in colour and has a very long snout ( $R$. Hutterer, pers. comm.),

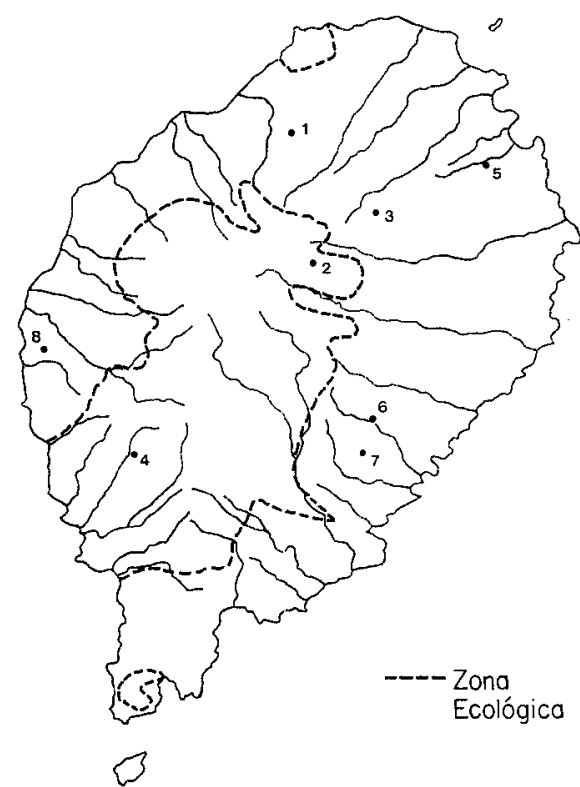

Figure 2. Successful trap sites and sightings of Crocidura thomensis. Numbers relate to the sites listed in Table 1.

unusually long hind feet and large ears (Heim de Balsac and Hutterer, 1982). The male neotype has a body length of $84 \mathrm{~mm}$, a tail length of $88 \mathrm{~mm}$ and feet (excluding claws) of 18.7 mm (Heim de Balsac and Hutterer, 1982). The specimen described by Bocage (1887) measured $16 \mathrm{~mm}$ from snout tip to eye and the female captured in 1991 weighed $12.5 \mathrm{~g}$ (Feiler et al., 1993). More detailed descriptions of the morphology of $C$. thomensis were given by Heim de Balsac and Hutterer (1982), with Bocage (1887, 1904b) and Feiler et al. (1993) also giving morphometric information. Heim de Balsac and Hutterer (1982) also explored the systematic position of $C$. thomensis in the Crocidura genus and suggested that São Tomé and Príncipe were colonized at different periods.

\section{Recent research}

No further efforts to catch and study $C$. thomensis occurred until 1989-91. In 1989 and 1990, 13 sites were unsuccessfully trapped using various sizes of Sherman trap, and $95 \times 48 \mathrm{~mm}$ 
break-back traps (two sites) and Longworth traps (11 sites), respectively (Atkinson et al., 1994). However, in 1990 one individual of $C$. thomensis was observed near the source of the Rio Xufexufe (Atkinson et al., 1994; Figure 2; Table 1). In 1991 a further eight sites were trapped, again using various sizes of Sherman trap and $95 \times 48 \mathrm{~mm}$ break-back traps, but only one male specimen was caught in a break-back trap on the Rio Angra Toldo (Feiler et al., 1993; Atkinson et al., 1994; Figure 2; Table 1). A live female was captured in a butterfly net as it ran across the bridge at Blublu waterfall and two other individuals were observed at Pico Maria Fernandez (Atkinson et al., 1994, H. Read, pers. comm; Figure 2; Table 1).

In 1992 a skull and some vertebrae of $C$. thomensis were found near Ponta Furada (Figure 2; Table 1). Examination of these suggested that they could have originated from a barn owl Tyto alba pellet.

\section{Distribution and habitat occurrence}

When Heim de Balsac and Hutterer (1982) published their paper on the Soricidae of the Gulf of Guinea islands, C. thomensis was only known from four mid-altitude sites between 700 and $1200 \mathrm{~m}$ (the fifth site on São Tomé is

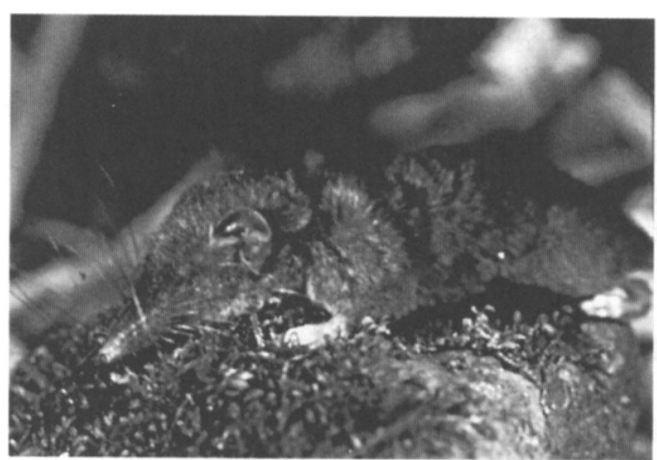

Crocidura thomensis (Jacob Fahr).

unknown). They said that this species inhabited plantations at medium altitudes and suggested that it had not adapted to plantations at lower altitudes due to the 'swarming' of the rat.

The 1990-92 research showed that C. thome$n$ sis has a far wider distribution (Figure 2) and a far greater altitudinal range (75-1200 m; Table 1) than previously believed, even if the site of the skull and vertebrae is discounted owing to the possibility of long-distance transport from the point of capture by an owl. Previously it had been written that this species relied on the forests of São Tomé for its continued survival (Nicoll and Rathbun, 1990). However, $C$. thomensis has been recorded in

Table 1. Site locations and descriptions of all captures and sightings of Crocidura thomensis

\begin{tabular}{|c|c|c|c|c|c|}
\hline Year & $\begin{array}{l}\text { No. } \\
\text { ind. }\end{array}$ & Site & Long./Lat. & $\begin{array}{l}\text { Altitude } \\
(\mathrm{m})\end{array}$ & Habitatt \\
\hline $1886^{\mathrm{a}}$ & 1 & Roça Minho $(1)^{*}$ & $0^{\circ} 16^{\prime} \mathrm{N} 6^{\circ} 31^{\prime} \mathrm{E}$ & 800 & Plantation \\
\hline $1896^{\mathrm{b}}$ & 1 & Santa Maria (2) & $0^{\circ} 20^{\prime} \mathrm{N} 6^{\circ} 36^{\prime} \mathrm{E}$ & 1200 & Plantation \\
\hline $1971^{\mathrm{C}}$ & 4 & Monte Café (3) & $0^{\circ} 18^{\prime} \mathrm{N} 6^{\circ} 31^{\prime} \mathrm{E}$ & 700 & Plantation \\
\hline $1971^{\mathrm{C}}$ & 2 & Monte Café (3) & $0^{\circ} 18^{\prime} \mathrm{N} 6^{\circ} 31^{\prime} \mathrm{E}$ & 800 & Plantation \\
\hline $1990^{\mathrm{d}}$ & 1 & Rio Xufexufe (4) & $0^{\circ} 11^{\prime} \mathrm{N} 6^{\circ} 32^{\prime} \mathrm{E}$ & 300 & Primary forest \\
\hline $1991^{\mathrm{e}}$ & 1 & Blublu Waterfall (5) & $0^{\circ} 19^{\prime} \mathrm{N} 6^{\circ} 43^{\prime} \mathrm{E}$ & 75 & Plantation \\
\hline $1991^{\mathrm{e}}$ & 1 & Rio Angra Toldo (6) & $0^{\circ} 11^{\prime} \mathrm{N} 6^{\circ} 38^{\prime} \mathrm{E}$ & 100 & Secondary forest and bamboo \\
\hline $1991^{\mathrm{e}}$ & 2 & Pico Maria Fernandez $(7)$ & $0^{\circ} 10^{\prime} \mathrm{N} 6^{\circ} 38^{\prime} \mathrm{E}$ & 400 & Primary forest \\
\hline $1992^{f}$ & 1 & Ponta Furada (8) & $0^{\circ} 14^{\prime} \mathrm{N} 6^{\circ} 29^{\prime} \mathrm{E}$ & 90 & Secondary forest \\
\hline
\end{tabular}

* Numbers in parentheses relate to site locations shown in Figure 2.

tSite habitats are those at the time of capture/sighting and may no longer be current.

Sources: a, Bocage, 1887; b, Bocage, 1904b; c, Heim de Balsac and Hutterer, 1982; d, Atkinson et al., 1994; e, Atkinson et al., 1994 and Feiler et al., 1993; f, Atkinson et al., 1994 and H. Read, pers. comm.

(C) $1996 \mathrm{FFI}$, Oryx, 30 (3), 195-201 
plantations, and in primary and secondary forest (Bocage, 1887, 1904b; Heim de Balsac and Hutterer, 1982; Atkinson et al., 1994; Table $1)$, but no sightings or captures have been made in the savannah area in the north-east of the island.

\section{Ecology and behaviour}

Little is known about $C$. thomensis but the sparse information available permits some speculation on its ecology and behaviour. Most captures have been of single individuals (Bocage, 1887, 1904b; Feiler et al., 1993; Atkinson et al., 1994), matching the understanding that most shrew species are solitary for much of their lives (Churchfield, 1990), although some Crocidura species show social tolerance (Nowak, 1991). R. de Naurois collected several individuals of $C$. thomensis at one site (Heim de Balsac and Hutterer, 1982) and in 1991 two shrews were observed chasing one another (Atkinson et al., 1994). These records could indicate that $C$. thomensis is one of the more socially tolerant Crocidura species or that the captures and observations were made during the breeding season and/or during territorial defence.

Most shrew species have a well-defined breeding season (Churchfield, 1990), although some tropical species of Crocidura breed throughout the year (Sheppe, 1972; Medway, 1978). The only indication of the breeding season of $C$. thomensis is de Naurois finding several juveniles in a nest of dead leaves, twigs and debris in December 1971 (Heim de Balsac and Hutterer, 1982; R. Hutterer, pers. comm.), in one of the dry periods separating the two wet seasons (approximately March-May and October-November; Jones and Tye, 1988; Juste and Fa, 1994).

Shrews are opportunistic predators of invertebrates, with their diet showing a wide diversity (Churchfield, 1990). The live specimen of C. thomensis captured in 1991 by J.H. ate most of two freshwater crustaceans (shrimp and $\mathrm{crab})$ and some invertebrates (moths, earthworms and grasshoppers) that were offered. The long snout of $C$. thomensis is likely to facilitate access to worms and insects in fissures and holes (R. Hutterer, pers. comm.).

Heim de Balsac and Hutterer (1982) speculated that $C$. thomensis was probably a jumping species because the hind feet are exceptionally long. However, none of the four individuals observed in 1990 and 1991 was seen to jump. The long limbs and long tail may facilitate climbing (R. Hutterer, pers. comm.), as with Sylvisorex megalura (Vogel, 1974) on mainland Africa, especially in the rugged terrain of São Tomé (Juste and Fa, 1994). Heim de Balsac and Hutterer (1982) also noted that this shrew must be tolerant of humans because the specimens collected by de Naurois in the early 1970s were discovered in immediate proximity to human activity; this is in common with many Crocidura species (Churchfield, 1990).

\section{Status and threats}

Of all captures and sightings of $C$. thomensis, only three have been in primary forest, all others occurring in plantation or secondary growth. This suggests that this shrew can survive in modified habitats and this, coupled with the fact that forest cover on São Tomé is 91.1 per cent (Interforest AB, 1990), indicates that it may not be under immediate threat from forest destruction. However, further forest clearance could have a detrimental impact. Many plantations have reverted to secondary forest, but the government's current land privatization programme may lead to the revitalization of these plantations (Atkinson et al., 1994). Untouched primary forest is now restricted to the mountainous regions, with a small remaining area of lowland rain forest in the south-western and central parts of the island (Jones, 1994), and the plantations and secondary forest are probably important for the survival of $\mathrm{C}$. thomensis.

If redevelopment of plantations occurs, a decline in habita suitability could lead to populations becoming fragmented and isolated, perhaps causing a decline in the viability of the remaining populations and possibly leading to local extinctions. The redevelopment of plantations would inevitably lead to an 
increase in pesticide use and insectivores are highly susceptible to many of the chemicals involved (Jefferies, 1972; Rudd et al., 1981; Churchfield, 1990; Osborn et al., 1991; Forsyth and Westcott, 1994). The use of pesticides was implicated in the decline of the São Tomé paradise flycatcher Terpsiphone atrochalybeia and the São Tomé oriole Oriolus crassirostris in the early 1970s (de Naurois, 1984a, b; these species are believed to have since recovered, Atkinson et al., 1994) and may be the reason that searches for $C$. thomensis at lower altitudes were unsuccessful during this period.

Predation by introduced mammals is also a threat. Human colonization led to the accidental introduction of ship rats and brown rats Rattus norvegicus. The African civet Civettictis civetta and the weasel Mustela nivalis may have been introduced deliberately to control the rats (Bocage, 1904b; Frade, 1958; Dutton, 1994). Domestic cats Felis catus are also present (Jones and Tye, 1988; Atkinson et al., 1994; Dutton, 1994).

Shrews are normally regarded as unpalatable to mammalian predators because of their distasteful odour (Churchfield, 1990). However, they form part of the diet of weasels (Erlinge, 1975; Moors, 1975; Tapper, 1976), and two viverrids - the large Indian civet Viverra zibetha (Medway, 1969) and banded mongoose Mungos mungo (Baxter, 1993) have been recorded to prey on shrews - indicating that the African civet could take $C$. thomensis. Domestic cats are also known to kill (but seldom eat) shrews (Churchfield, 1990), and rats are recorded as preying on small mammals (Brosset, 1963; Davies, 1979). Bearing in mind their probable long association on São Tomé (Dutton, 1994), it seems unlikely that these predators would be the sole cause of any extinctions, but coupled with other threats such predation could tip the balance against the survival of the shrew.

Nicoll and Rathbun (1990) considered C. thomensis to be 'very rare' and the species is currently listed as 'Insufficiently Known' by the IUCN (Groombridge, 1993). Using the criteria for the new IUCN Red List Categories (IUCN, 1994) C. thomensis should be categorized as 'Vulnerable: $B 1+2 c^{\prime}$. Both the extent of occurrence and area of occupancy of this shrew are less than the minimum limits of 20,000 and $2000 \mathrm{sq} \mathrm{km}$, respectively. In addition, it has been recorded from fewer than 10 locations and both the extent and quality of habitat is projected to decline with land privatization and plantation regeneration.

\section{Conservation action}

Nicoll and Rathbun (1990) recommended that São Tomés forests needed protection to conserve $C$. thomensis. These forests have also attracted conservation interest because of their ornithological endemism and were ranked second out of 75 African forests by Collar and Stuart (1988).

A Zona Ecológica (national park; Figure 2) was gazetted in 1993 (Jones, 1994), the main part encompassing forest in the lowland south-west and central highlands of São Tomé, including the untouched primary forest and the majority of the remaining lowland rain forest. It was first delineated by BDPA (1985) and was reaffirmed by Jones and Tye (1988), Interforest $\mathrm{AB}(1990)$ and Jones et al., (1991). Atkinson et al., (1994) suggested minor but important extensions for further avifaunal protection. It is likely that the zona will provide significant protection for $C$. thomensis, even though it includes only two sites where the species has been recorded.

Further protection should be provided in other parts of the island and every effort should be made to minimize the impact of plantation redevelopment on $C$. thomensis. Pesticide application techniques, in particular, should be reviewed to minimize any environmental contamination.

\section{Acknowledgements}

We thank all those people and organizations who supported the expeditions in 1989, 1990 and 1991. Special thanks go to the other participants of these expeditions: James Alexander, Phil Atkinson, Carsten Brühl, Joanne Dutton, Jakob Fahr, Alfred Feiler, Tilo Nadler, Tilman Nill, Nic Peet, Peter Schütz, Vanessa Sequeira and Peter Widmann. Thanks must also go to Adrian Barnett, Jakob Fahr, 
Rainer Hutterer, Peter Jones and Helen Read, who provided additional information for this paper and to Brian Groombridge, Tony Hutson, Paula Jenkins and Beat Schätti for additional discussions. Also to Claire Graham, Hiltrun Ratz, Ruth Maier and Vanessa Sequeira for doing various translations, to Lisa Norton and Phil Atkinson for aiding the preparation of Figures 1 and 2, respectively, and to Phil Atkinson, Adrian Barnett, Gen Broad, Rainer Hutterer and Peter Jones for commenting on drafts of this paper.

\section{References}

Atkinson, P.W., Dutton, J.S., Peet, N.B. and Sequeira, V.A.S. 1994. A Study of the Birds, Small Mammals, Turtles and Medicinal Plants of São Tomé with notes on Principe. Birdlife International Study Report No. 56. Birdlife International, Cambridge.

Atkinson, P.W., Peet, N.B. and Alexander, J. 1991. The status and conservation of the endemic bird species of São Tomé and Príncipe, West Africa. Bird Conservation International, 1, 255-282.

Baxter, R.M. 1993. Banded mongoose predation on a shrew, Crocidura $f$. flavescens. Mammalia, 57, 145-146.

BDPA. 1985. Potencialidedes Agricoles: Republica Democratica de São Tomé Prìncípe. Bureau pour le Developement de la Production Agricole, Paris.

Bocage, J.V. Barboza du. 1887. Sur un mammifère nouveau de l'Ile de St. Thomé. Jour. Acad. Sci. Lisboa, 11, 212-213.

Bocage, J.V. Barboza du. 1904a. Contribution à la faune des quatre îsles du Golfe du Guinée. 2. Ile du Prince. Jour. Acad. Sci. Lisboa, 7, 25-54.

Bocage, J.V. Barboza du. 1904b. Contribution à la faune des quatre îsles du Golfe du Guinée. 4. Ile de São Tomé. Jour. Acad. Sci. Lisboa, 7, 65-96.

Brosset, A. 1963. Statut actuel des mammifères des îles Galàpagos. Mammalia, 27, 323-338.

Brühl, C. 1993. Überlick über Geographie, Geologie, Klima und Vegetationsformationen der Insel São Tomé (Golf von Guinea). Faun. Abh. Mus. Tierk. Dresden, 19, 5-16.

Churchfield, S. 1990. The Natural History of Shrews. Christopher Helm, London.

Collar, N.J. and Stuart, S.M. 1985. Threatened Birds of Africa and Related Islands. International Council for Bird Preservation, Cambridge.

Collar, N.J. and Stuart, S.M. 1988. Key Forests for Threatened Birds of Africa. Monograph 3, International Council for Bird Preservation, Cambridge.

Davies, R.A. 1979. Unusual behaviour by Rattus norvegicus. J. Zool. Lond. 188, 298.

Dutton, J.S. 1994. The impact of introduced mammals on biodiversity in the República
Democrática de São Tomé e Príncipe. Biodiversity and Conservation, 3, 927-938.

Erlinge, S. 1975. Feeding habits of the weasel Mustela nivalis in relation to prey abundance. Oikos, 26, 378-384.

Exell, A.W. 1944. Catalogue of the Vascular Plants of S. Tomé (with Principe and Annobon). British Museum (Natural History), London.

Exell, A.W. 1956. Supplement to the Catalogue of the Vascular Plants of S. Tomé (with Principe and Annobon). British Museum (Natural History), London.

Feiler, A., Haft, J. and Widmann, P. 1993. Beobachtungen und Untersuchungen an Säugetieren der Insel São Tomé (Golf von Guinea) (Mammalia). Faun. Abh. Mus. Tierk. Dresden, 19, 21-35.

Figueiredo, E. 1994. Diversity and endemism of angiosperms in the Gulf of Guinea islands. Biodiversity and Conservation, 3, 785-793.

Forsyth, D.J. and Westcott, N.D. 1994. Carbifuran residues in grasshoppers and vegetation from aerially sprayed prairie pastures: potential effects on wildlife. Environmental Toxicology $\&$ Chemistry, 13, 299-306.

Frade, F. 1958. Aves e mammiferos das Ilhas de São Tomé e do Príncipe - notas de sistematica e de proteccao a fauna. Conferencia Internacional dos Africanistas Ocidentais, Lisboa, 4, 137-150.

Groombridge B. (ed.) 1993. 1994 IUCN Red List of Threatened Animals. IUCN, Gland, Switzerland.

Günther, R. and Feiler, A. 1985. Die Vögel der Insel São Tomé. Mitt. zool. Mus. Berlin, 61 Suppl. Ann Orn., 9, 3-28.

Heim de Balsac, H. and Hutterer, R. 1982. Les Soricidae (Mammifères Insectivores) des îsles du Golfe du Guinée: faits nouveaux et problèmes biogéographiques. Bonn. Zool. Beitr. 33, 133-150.

Hodges, T. and Newitt, M. 1988. São Tomé and Principe from Plantation Colony to Microstate. Westview Press, Boulder, Colorado.

Interforest AB. 1990. Democratic Republic of São Tomé and Principe: 1, Results of National Forest Inventory; 2, National Forest Inventory, Study of Supply and Demand of Primary Forest Products - Conclusions and Recommendations. Interforest $\mathrm{AB}$, São Tomé, RDSTP.

IUCN. 1994. IUCN Red List Categories, as approved by the 40th meeting of the IUCN Council, 30 November 1994. IUCN, Gland, Switzerland.

Jefferies, D.J. 1972. Organochlorine insecticide residues in British bats and their significance. J. Zool. Lond. 166, 245-263.

Jones, P.J. 1994. Biodiversity in the Gulf of Guinea: an overview. Biodiversity and Conservation, 3, 772-784.

Jones, P.J., Burlison, J.P. and Tye, A. 1991. 
Conservação dos Ecossistemas Florestais na República Democrática de São Tomé e Príncipe. IUCN, Gland, Switzerland.

Jones, P.J. and Tye, A. 1988. A Survey of the Avifauna of São Tomé and Príncipe. ICBP Study Report No. 24. ICBP, Cambridge, England.

Juste, B.J. and Fa, J.E. 1994. Biodiversity conservation in the Gulf of Guinea islands: taking stock and preparing action. Biodiversity and Conservation, 3, 759-771.

Juste, B.J. and Ibañez, C. 1994. Bats of the Gulf of Guinea islands: faunal composition and origins. Biodiversity and Conservation, 3, 837-850.

Medway, Lord. 1969. The Wild Mammals of Malaya and Offshore Islands including Singapore. Oxford University Press, London.

Medway, Lord. 1978. The Wild Mammals of Malaya (Peninsular Malaysia) and Singapore. Oxford University Press, Kuala Lumpur.

Moors, P.J. 1975. The food of weasels (Mustela nivalis) on farmland in north-east Scotland. J. Zool. Lond. 177, 455-461.

Nadler, T. 1993. Beiträge zur avifauna der Insel São Tomé (Golf von Guinea) (Aves). Faun. Abh. Mus. Tierk. Dresden, 19, 37-58.

de Naurois, R. 1984a. La moucherolle endemique de l'île de São Tomé, Terpsiphone atrochalybeia (Thomson 1842). Alauda, 52, 31-44.

de Naurois, R. 1984b. Le loriot endemique de l'île de São Tomé (Golfe de Guinée) Oriolus crassirostris (Hartlaub). Cyanopica, 3, 121-134.

Nicoll, M.E. and Rathbun, G.B. 1990. African Insectioora and Elephant-Shrews: An Action Plan for their Conservation. IUCN, Gland, Switzerland.

Nowak, R.M. 1991. Walkers Mammals of the World, 5th edn, Vol. 1. The Johns Hopkins University Press, Baltimore.

Osborn, D., Shore, R.F. and Mountford, J.O. 1991. Impacts of agriculture on wild plants and animals in the UK: chemical impacts in perspective. In Chemistry, Agriculture and the Environment (ed. M. L. Richardson), pp. 11-30. The Royal Society of Chemistry, Cambridge.

Peet, N.B. and Atkinson, P.W. 1994. The biodiversity and conservation of the birds of São Tomé and Príncipe. Biodiversity and Conservation, 3, 851-867.

Rudd, R.L., Craig, R.B. and Williams, W.S. 1981. Trophic accumulation of DDT in a terrestrial food web. Environmental Pollution (Series A), 25, 219-228.

Sheppe, W.A. 1972. The annual cycle of small mammal populations in a Zambian floodplain. $J$. Mammalogy, 53, 445-460.

Tapper, S.C. 1976. The diet of weasels, Mustela nivalis and stoats, Mustela erminea during early summer, in relation to predation on gamebirds. J. Zool. Lond. 179, 219-224.

Vogel, P. 1974. Note sur le comportement arboricole de Sylvisorex megalura (Soricidae, Insectivora). Mammalia, 38, 171-176.

John Dutton, Biological Sciences, University of East Anglia, Norwich NR4 7TJ, UK.

Jan Haft, Grasbrunner Weg 3a, 85630 Grasbrunn 1, Germany. 